\title{
Sediment sources in the Upper Severn catchment: a fingerprinting approach
}

\author{
A. L. Collins, ${ }^{1}$ D. E. Walling ${ }^{1}$ and G. J. L. Leeks ${ }^{2}$ \\ 1 Department of Geography, University of Exeter, Exeter, Devon, EX4 4RJ (UK) \\ 2 Institute of Hydrology, Wallingford, Oxon, OX10 8BB (UK)
}

\section{Abstract}

\begin{abstract}
Suspended sediment sources in the Upper Severn catchment are quantified using a composite fingerprinting technique combining statistically-verified signatures with a multivariate mixing model. Composite fingerprints are developed from a suite of diagnostic properties comprising trace metal ( $\mathrm{Fe}, \mathrm{Mn}, \mathrm{Al}$ ), heavy metal ( $\mathrm{Cu}, \mathrm{Zn}, \mathrm{Pb}, \mathrm{Cr}, \mathrm{Co}, \mathrm{Ni})$, base cation $(\mathrm{Na}, \mathrm{Mg}, \mathrm{Ca}, \mathrm{K}$ ), organic $(\mathrm{C}, \mathrm{N})$, radiometric $\left({ }^{137} \mathrm{Cs},{ }^{210} \mathrm{~Pb}\right)$, and other (total $\left.\mathrm{P}\right)$ determinands. A numerical mixing model, to compare the fingerprints of contemporary catchment source materials with those of fluvial suspended sediment in transit and those of recent overbank floodplain deposits, provides a means of quantifying present and past sediment sources respectively. Sources are classified in terms of eroding surface soils under different land uses and channel banks. Eroding surface soils are the most important source of the contemporary suspended sediment loads sampled at the Institute of Hydrology flow gauging stations at Plynlimon and at Abermule. The erosion of forest soils, associated with the autumn and winter commercial activities of the Forestry Commission, is particularly evident. Reconstruction of sediment provenance over the recent past using a sediment core from the active river floodplain at Abermule, in conjunction with a ${ }^{137} \mathrm{Cs}$ chronology, demonstrates the significance of recent phases of afforestation and deforestation for accelerated catchment soil erosion.
\end{abstract}

\section{Introduction}

Although recent research has demonstrated a growing awareness of the role of suspended sediment in the transport of nutrients and contaminants (Ongley et al., 1992), in non-point pollution (Knisel, 1980), in sediment-water interactions which influence water quality (UNESCO, 1978) and in damage to aquatic ecology (Cordone and Kelley, 1961), less attention has been focused upon the need to control and manage sediment in river basins (Braune and Looser, 1990). However, where attempts are made to develop sediment control and management strategies, the resources available are frequently so limited that effective targetting of such activities becomes an important requirement. One important constraint on the implementation of effective control and management strategies is the sparsity of information on sediment provenance (Walling, 1990; Hudson, 1990). In many drainage basins, the primary sediment sources have not been identified and it is therefore difficult to pinpoint the most cost-effective means of reducing sediment fluxes.

Traditionally, sediment source information has been assembled using a range of direct monitoring techniques. These have included visual appraisal of potential sources, both from photographs and in the field (Kirkbridge and
Reeves, 1993); surveying of rills and gullies (Duck and McManus, 1987); and the monitoring of potential sources using profilometers (Toy, 1983), erosion pins (Haigh, 1977; Lawler, 1992), or aerial photogrammetry in combination with topographic mapping and GIS (Ritchie et al., 1994). Measurements of river loads have also been used to quantify the relative contributions of suspended sediment from individual sub-basins (Walling and Webb, 1987). Such direct monitoring is, however, costly and timeconsuming and it is restricted by many operational difficulties as well as by important spatial and temporal sampling constraints (Peart and Walling, 1988; Loughran and Campbell, 1995).

In consequence, the fingerprinting approach has attracted increasing attention as an alternative indirect approach to identifying sediment sources (Walling and Kane, 1984; Peart and Walling, 1988). As such, it has proved valuable for elucidating the relative contributions from individual source types e.g. surface soils under different land uses and channel banks (Peart and Walling, 1986; Slattery et al., 1995), for establishing the spatial location of sediment sources defined in terms of tributary subbasins (Caitcheon, 1993; Collins et al., 1996) or geological sub-areas (Klages and Hsieh, 1975; Walling and 
Woodward, 1995), and for reconstructing recent changes in sediment provenance (Woodward et al., 1992; Collins $e t$ $a l ., 1997 b)$. In essence, the fingerprinting approach uses the physical and chemical properties of sediment to infer its provenance and involves, firstly, the selection of diagnostic properties which discriminate potential sources in an unequivocal manner, and secondly, comparison of the fingerprint properties in the potential sources with the corresponding values for sediment samples, in order to estimate the relative importance of individual sources.

Traditionally the search for diagnostic properties has concentrated upon single-component signatures. These have encompassed a wide range of mineralogic (Wall and Wilding, 1976; Garrad and Hey, 1989), colorimetric (Grimshaw and Lewin, 1980; Peart, 1993), mineralmagnetic (Oldfield et al., 1979; Bonnett et al., 1989), geochemical (Lewin and Wolfenden, 1978; Jones et al., 1991), organic (Brown, 1985; Santiago et al., 1992), radiometric (Walling and Woodward, 1992; Murray et al., 1993), isotopic (Salomans, 1975; Salomans and Eysink, 1981) and physical, e.g. absolute particle size (Lambert and Walling, 1986; Sutherland and Bryan, 1990), properties and property ratios. However, a realisation that the search for a single diagnostic property is likely to prove elusive and that spurious source-sediment linkages can result from the use of individual fingerprint properties, has resulted in the development of composite fingerprinting procedures. These employ multicomponent signatures comprising several diagnostic properties selected from either a particular property subset e.g. several mineral-magnetic (Oldfield and Clark, 1990) or radiometric (He and Owens, 1995) parameters, or from a range of different subsets e.g. several mineral-magnetic, radiometric and organic properties (Walling et al., 1993; Walling and Woodward, 1995). The use of composite fingerprints has been complemented by the replacement of simple qualitative interpretation with more rigorous quantitative procedures involving source discrimination using statistical testing and source ascription based on multivariate mixing models ( $\mathrm{Yu}$ and Oldfield, 1989; 1993; Walling et al., 1993; Slattery et al., 1995; Collins et al., 1996; 1997a; 1997b).

This contribution applies a composite fingerprinting technique which combines statistically-verified multicomponent signatures and a multivariate mixing model, to quantify both present and past sediment sources in the Upper Severn catchment, upstream of Abermule $\left(580 \mathrm{~km}^{2}\right)$. Sediment sources are characterised in terms of eroding surface soils beneath different land uses (forestry and pasture) and eroding channel banks. The bulk of this work was undertaken during 1992-1994 as part of a wider study of sediment sources in the Severn basin above Bewdley (Collins, 1995).

\section{Study Area}

Figure 1 shows the location and extent of the Upper Severn catchment investigated in this study. The bulk of the work focused upon the headwater catchment at Plynlimon $\left(8.7 \mathrm{~km}^{2}\right)$, where Ordovician and Silurian shales and mudstones give rise locally to steep slopes in excess of $20^{\circ}$ and where the topography is of rolling hills dissected by steep valleys. Land use within the Severn headwaters is dominated by commercial coniferous forestry, although above the tree line pasture and rough moorland are also important. Actively eroding channel banks (up to $1.5 \mathrm{~m}$ in height) are widespread. Annual suspended sediment yields are estimated to be in the range $24.4-57.1 \mathrm{t} \mathrm{km}^{-2} \mathrm{yr}^{-1}$ during periods of clearfelling (Leeks and Roberts, 1987) but are substantially lower during periods of stability. Suspended sediment sampling sites were located at the Institute of Hydrology Hafren, Upper Hore and Severn Trapezoidal Flume flow gauging stations. These sites provided a good spatial coverage of the two major tributaries (Afon Hore and Afon Hafren) comprising this catchment (see Fig. 1A). An additional sampling site was chosen further downstream at the Abermule flow gauging station (see Fig. 1B) which has a total catchment area of $580 \mathrm{~km}^{2}$. Downstream towards Abermule, slopes become progressively less steep and commercial forestry is replaced by permanent pasture.

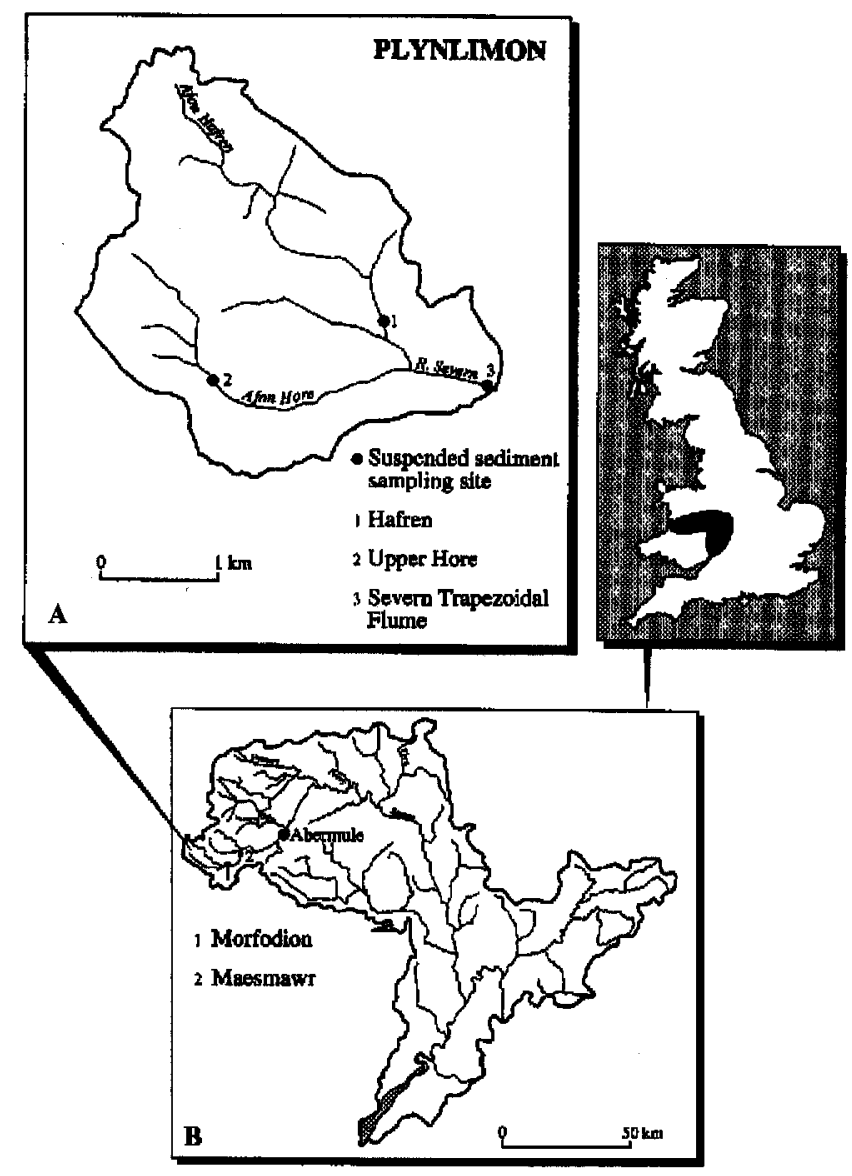

Fig. 1. Location and extent of the Upper Severn study area. 


\section{The Approach}

To quantify contemporary sediment provenance in the Upper Severn, the fingerprint properties of suspended sediment sampled in transit at the three Plynlimon flow gauging stations and at Abermule were compared with those of the equivalent size fraction of potential source materials within the upstream catchment. For reconstructing recent changes in sediment sources for the Upper Severn at Abermule, the physical and chemical properties of recent floodplain deposits taken from this site were compared with those of the same contemporary upstream source materials. Underpinning the latter is the assumption that downcore geochemical variability is actually diagnostic of historical fluctuations in the relative contributions from individual sources as opposed to diagenetic changes. Although the random variability associated with natural fluctuations in the relative significance of sources between distinct flood events may become obscured by other factors such as flood seasonality, this potential problem is minimized by the use of a coarse sectioning interval. However, interpretation of the geochemical record preserved in overbank deposits in terms of recent changes in sediment sources, using the fingerprinting approach, is also dependent upon the establishment of a chronology for the sediment profile. This study uses ${ }^{137} \mathrm{Cs}$ dateable horizons to establish an absolute chronology for the overbank deposits (cf. Walling and He, 1992; Collins et al., 1997b). It should, however, be recognised that use of recent floodplain sediments permits reconstruction only of changes in the provenance of the sediment deposited by those flood events resulting in overbank deposition.

\section{Sample Collection and Analysis}

\section{FIELD SAMPLING}

Fieldwork involved collection of representative source material samples, bulk suspended sediment sampling, as well as floodplain coring. Source material sampling involved the collection of representative surface soil from forest and pasture areas and subsurface material from channel banks. Care was taken to ensure that only material susceptible to erosion (i.e. the top $0-2 \mathrm{~cm}$ of surficial sources and channel banks exhibiting active erosion scars) was sampled. Consequently, the sampling of surface soil within forest areas was biased towards likely sediment sources e.g. eroding trackways, roadsides and drains, as opposed to soils directly protected by the forest canopy and thick litter layer. Within the Severn headwater catchment at Plynlimon, 30 source material samples were collected, i.e. 10 surface samples from each of forest and pasture and 10 representative of channel banks. Within the Upper Severn catchment above Abermule, a further 30 source material samples were collected, i.e. 10 surface samples from each of forest and pasture and 10 from channel banks.
Representative bulk water samples were collected during storm events from each gauging station using a submersible pump powered by a portable generator. Sampling was stratified to encompass a range of ambient suspended sediment concentrations and anticipated seasonal, interand intra-storm variations in sediment sources and properties (Ongley et al., 1981). A total of 15 samples were collected from the Plynlimon gauging stations and 10 from Abermule.

In addition, a single sediment core was collected from the floodplain at Abermule using a motor-driven percussion corer and portable winch device. The core tube had an internal diameter of $6.9 \mathrm{~cm}$ and a length of $80 \mathrm{~cm}$.

\section{LABORATORY ANALYSIS}

All source material samples were air-dried on porous plates, gently disaggregated using a pestle and mortar and then dry-sieved to $<63 \mu \mathrm{m}$ to facilitate direct comparison with contemporary suspended sediment samples which were found to consist almost exclusively of the $<63 \mu \mathrm{m}$ fraction. The latter were de-watered using a continuous-flow centrifuge and freeze-dried prior to more detailed laboratory analysis. The floodplain core from Abermule was sectioned at $2 \mathrm{~cm}$ intervals, oven-dried at low temperatures (40$50^{\circ} \mathrm{C}$ ) and dry-sieved to $<63 \mu \mathrm{m}$ to facilitate direct comparison with contemporary catchment source materials.

Laboratory analysis of source materials, suspended sediment samples and the floodplain core sections encompassed a range of potential fingerprint properties comprising several property subsets, i.e. trace metals $(\mathrm{Fe}$, $\mathrm{Mn}, \mathrm{Al}$ ), heavy metals $(\mathrm{Cu}, \mathrm{Zn}, \mathrm{Pb}, \mathrm{Cr}, \mathrm{Co}, \mathrm{Ni})$, base cations $(\mathrm{Na}, \mathrm{Mg}, \mathrm{Ca}, \mathrm{K})$, organics $(\mathrm{C}, \mathrm{N})$, radionuclides $\left({ }^{137} \mathrm{Cs},{ }^{210} \mathrm{~Pb}\right)$ and other (total $\left.\mathrm{P}\right)$ determinands. Extraction of $\mathrm{Fe}, \mathrm{Mn}$ and $\mathrm{Al}$ involved both pyrophosphate-dithionite (Bascomb, 1968) and oxalate (Deb, 1950) methods. Heavy metal extraction used direct acid digestion (Allen, 1989), whilst acid ammonium acetate extracted base cations (Qui and Zhu, 1993). All extract concentrations were determined using AAS, with either an air/acetylene or nitrous oxide/acetylene flame. Direct determination of $\mathrm{C}$ and $\mathrm{N}$ used a Carlo Erba Elemental Analyser, and colorimetric determination of total $\mathrm{P}$ used UVS after extraction with perchloric acid (Olsen and Dean, 1965). ${ }^{137} \mathrm{Cs}$ and excess ${ }^{210} \mathrm{~Pb}$ assay involved gamma spectrometry using lowbackground $\mathrm{HPGe}$ detectors linked to a multichannel analyser. Analysis of the depth distribution of ${ }^{137} \mathrm{Cs}$ within the floodplain core from Abermule identified two peaks. Assuming the lower to be the peak of atomic weapons testing in 1963 and the upper as that relating to the Chernobyl accident of 1986, time-averaged deposition rates were established. Extrapolation of these rates over the depth of the core provided an approximate, absolute chronology (Walling and He, 1992; Foster and Walling, 1994; Collins et al., 1997b). To enable a particle size correction factor to be calculated, the absolute particle size composition of 
individual samples was determined using a Malvern Mastersizer, after sample pre-treatment with hydrogen peroxide and sodium hexametaphosphate (McManus, 1988).

\section{Fingerprinting Sediment Sources}

\section{THE PROCEDURE}

The composite fingerprinting procedure documented by Collins et al. $(1997 \mathrm{a} ; 1997 \mathrm{~b})$ was used to quantify present and past sediment sources in the Upper Severn catchment. Application of this procedure involved:

a) Use of a two stage statistical selection procedure to identify, from an extensive list of individual properties, composite fingerprints capable of discriminating contemporary catchment source materials characterised in terms of individual source types, either within the Plynlimon headwater catchment or in the Upper Severn above Abermule.

b) Use of a multivariate sediment-mixing model to compare the composite fingerprints of contemporary catchment source and suspended sediment samples, in order to estimate the relative contribution from individual source types to the sediment load sampled at each flow gauging station.

c) Use of the same model to compare the composite fingerprints of contemporary source materials with those of the individual horizons comprising the Abermule floodplain core, in order to estimate, in combination with a ${ }^{137} \mathrm{Cs}$ chronology, historical fluctuations in the relative contribution from individual source types to the sampled overbank sediment profile.

\section{SOURCE DISCRIMINATION}

In stage one, of the two stage statistical selection procedure proposed by Collins et al. (1997a; 1997b) all fingerprint properties were tested for their ability to discriminate source type on a simple surface (i.e. forest and pasture material) versus subsurface (i.e. channel bank material) basis, using the Mann-Whitney U-test. This statistical selection procedure assumed that, if an individual fingerprint property is unable to distinguish surface from subsurface source types, it is unlikely to discriminate a more complex classification of source types. Probabilities for the Mann-Whitney U-test are presented in Tables 1 and 2. The critical P-value is 0.05 and, in each case, most of the fingerprint properties yield extremely significant probabilities and so provide effective measures for source discrimination. These results confirm that there is a $95 \%$ probability that differences between the mean values of these fingerprint properties for surface and subsurface sources are not the result of random variations. A higher probability was not selected to ensure that the majority of fingerprint properties passed stage one. Success at this stage was a criterion for entering parameters in stage two.

In stage two, Multivariate Discriminant Function Analysis was employed to identify composite fingerprints capable of distinguishing source types on a more detailed basis, involving surface soils from forest and pasture areas and channel banks. Composite fingerprints were constructed using the minimization of Wilks' lambda as a stepwise selection algorithm. A lambda of 1 occurs when all group means are equal, whilst values close to zero occur when within-group variability is less than inter-group variability. Composite fingerprints affording comprehensive discrimination of individual source types will therefore be

Table 1. Mann-Whitney U-test probabilities for a comparison of surface and subsurface fingerprint properties in the Plynlimon headwater catchment.

\begin{tabular}{|c|c|c|c|}
\hline Fingerprint Property & P-value & Fingerprint Property & P-value \\
\hline pyrophosphate $\mathrm{Fe}$ & 0.0002 & $\mathrm{Cr}$ & 0.0002 \\
\hline dithionite $\mathrm{Fe}$ & 0.0002 & Co & 0.0001 \\
\hline pyrophosphate $\mathrm{Mn}$ & 0.0046 & $\mathrm{Ni}$ & 0.3176 \\
\hline dithionite $\mathrm{Mn}$ & 0.0156 & total P & 0.0001 \\
\hline pyrophosphate $\mathrm{Al}$ & 0.0046 & $\mathrm{C}$ & 0.0122 \\
\hline dithionite $\mathrm{Al}$ & 0.0002 & $\mathbf{N}$ & 0.0122 \\
\hline total of pyro. and dith. Fe & 0.0002 & $\mathrm{Na}$ & 0.0002 \\
\hline total of pyro. and dith. $\mathrm{Mn}$ & 0.0173 & $\mathrm{Mg}$ & 0.0002 \\
\hline total of pyro. and dith. Al & 0.0002 & $\mathrm{Ca}$ & 0.0002 \\
\hline oxalate $\mathrm{Fe}$ & 0.0002 & $\mathbf{K}$ & 0.0002 \\
\hline oxalate $\mathrm{Mn}$ & 0.0539 & ${ }^{137} \mathrm{Cs}$ & 0.0002 \\
\hline oxalate $\mathrm{Al}$ & 0.0006 & ${ }^{210} \mathrm{~Pb}$ & 0.0003 \\
\hline $\mathrm{Cu}$ & 0.0002 & & \\
\hline $\mathrm{Zn}$ & 0.0002 & & \\
\hline $\mathrm{Pb}$ & 0.0013 & & \\
\hline
\end{tabular}

(critical P-value $=0.05$ ) 
Table 2. Mann-Whitney U-test probabilities for a comparison of surface and subșurface fingerprint properties in the Upper Severn above Abermule.

\begin{tabular}{|c|c|c|c|}
\hline Fingerprint Property & P-value & Fingerprint Property & P-value \\
\hline pyrophosphate $\mathrm{Fe}$ & 0.0006 & $\mathrm{Cr}$ & 0.0002 \\
\hline dithionite Fe & 0.0056 & Co & 0.0002 \\
\hline pyrophosphate $\mathrm{Mn}$ & 0.0002 & $\mathrm{Ni}$ & 0.0056 \\
\hline dithionite $\mathrm{Mn}$ & 0.0002 & total P & 0.0011 \\
\hline pyrophosphate $\mathrm{Al}$ & 0.0002 & C & 0.0122 \\
\hline dithionite $\mathrm{Al}$ & 0.0048 & $\mathbf{N}$ & 0.0222 \\
\hline total of pyro. and dith. Fe & 0.0017 & $\mathrm{Na}$ & 0.0004 \\
\hline total of pyro. and dith. Mn & 0.0020 & $\mathrm{Mg}$ & 0.0004 \\
\hline total of pyro. and dith. Al & 0.0005 & $\mathrm{Ca}$ & 0.0004 \\
\hline oxalate $\mathbf{F e}$ & 0.0666 & $\mathbf{K}$ & 0.0004 \\
\hline oxalate $\mathrm{Mn}$ & 0.0049 & ${ }^{137} \mathrm{Cs}$ & 0.0002 \\
\hline oxalate Al & 0.0333 & ${ }^{210} \mathrm{~Pb}$ & 0.0003 \\
\hline $\mathrm{Cu}$ & 0.0002 & & \\
\hline $\mathrm{Zn}$ & 0.0002 & & \\
\hline $\mathrm{Pb}$ & 0.0004 & & \\
\hline
\end{tabular}

(critical P-value $=0.05)$

associated with lower lambda values. Tables 3 and 4 present the final results of the Discriminant Function Analysis for the Plynlimon headwater catchment and the Upper Severn catchment upstream of Abermule, respectively. Both signatures yield lambda values close to zero and comprise individual properties from a range of different subsets. This highlights the importance of incorporating an extensive list of potential fingerprint properties with differing environmental behaviour into the composite fingerprinting approach (Walling et al., 1993; Collins, 1995; Collins et al., 1997a). This is further underscored by the fact that, although $\mathrm{Cu}, \mathrm{Zn}, \mathrm{Pb}$ and $\mathrm{Ni}$ correctly distinguish $100 \%$ of the source type samples upstream of Abermule, inclusion of dithionite $\mathrm{Mn}$ and $\mathrm{Mg}$ into this composite fingerprint, results in a further reduction of Wilks' lambda (see Table 4). It should also be noted that ${ }^{137} \mathrm{Cs}$ and ${ }^{210} \mathrm{~Pb}$ cannot be used to compare contemporary source materials with recent floodplain deposits as the downcore fluctuations of these radionuclides will reflect their depositional histories and environmental decay, as opposed to recent variations in the relative contributions from individual source types. However, neither of these radionuclides are included in the set of properties used to establish the composite fingerprint for historical sediment sources in the catchment area above Abermule, as the same composite fingerprint is employed to interpret the source of both contemporary suspended sediment and overbank floodplain deposits.

\section{SOURCE QUANTIFICATION}

The multivariate sediment-mixing model documented by Collins et al. (1997a; 1997b) was employed in conjunction with the information afforded by the composite fingerprints, to quantify present and past relative contributions from individual sediment source types within the Upper Severn study area. This model seeks to satisfy the following constraints:

a) The relative contributions from each individual source types to either the contemporary suspended sediment loads sampled at the flow gauging stations, or to each horizon comprising the floodplain core from Abermule, must all be non-negative, i.e.:

$$
0 " P_{s} " 1
$$

b) The relative contributions from each individual source type to either the contemporary suspended sediment loads sampled at the flow gauging stations, or to each horizon comprising the floodplain core from Abermule, must all sum to unity, i.e.:

$$
\sum_{s=1}^{n} P s=1
$$

Table 3. Final results of the stepwise Discriminant Function Analysis for the Plynlimon headwater catchment.

\begin{tabular}{lcc}
\hline $\begin{array}{l}\text { Fingerprint } \\
\text { Property }\end{array}$ & $\begin{array}{c}\text { Wilks' } \\
\text { Lambda }\end{array}$ & $\begin{array}{c}\text { Cumualtive \% Source } \\
\text { Type Samples } \\
\text { Classified Correctly }\end{array}$ \\
\hline $\mathrm{N}$ & 0.0796 & 83.33 \\
$\mathrm{Cu}$ & 0.0013 & 96.67 \\
${ }^{137} \mathrm{Cs}$ & 0.0001 & 100.00 \\
\hline
\end{tabular}


An equation (equation 3) is established for each property comprising each composite fingerprint. This equation compares the concentration of that property in either the contemporary suspended sediment sampled from each gauging station, or within each horizon constituting the Abermule floodplain core, with the sum of the concentrations characterising contemporary catchment source materials. As the set of equations pertaining to each composite signature is over-determined, optimization of the estimates for the relative contributions from individual source types is achieved by minimizing an objective function. This is measured by the sum of squares of the weighted relative errors, viz.:

$$
\begin{gathered}
\sum_{i=1}^{n}\left\{\left(C i-\left(P s_{f} \cdot S i_{f} \cdot Z_{f} \cdot O_{f}+P s_{p} \cdot S i_{p} \cdot Z_{p} \cdot O_{p}+\right.\right.\right. \\
\left.\left.\left.P s_{c b} \cdot S i_{c b} \cdot Z_{c b} \cdot O_{c b}\right)\right) / C i\right\}^{2} W i
\end{gathered}
$$

where:

$C i=$ concentration of tracer property (i) in either contemporary suspended sediment samples from each gauging station or in each horizon constituting the Abermule floodplain core

$P_{S}=$ relative contribution from each individual source type, where $f_{f}=$ forest $_{p}=$ pasture $_{c b}=$ channel bank

$S i=$ concentration of tracer property (i) in each individual source type

$Z \quad$ = particle size correction factor (ratio of either suspended sediment sample or core horizon specific surface area to mean specific surface area for each individual source type)

$O=$ organic matter content correction factor (ratio of suspended sediment sample organic carbon content to mean organic carbon content for each individual source type)

$W i=$ tracer specific weighting

The fingerprint property data for the contemporary catchment source materials are aggregated to provide a single mean value for each individual source type; this is then used in the mixing model algorithm to estimate the relative importance of present or past sediment sources in the

Table 4. Final results of the stepwise Discriminant Function Analysis for the Upper Severn above Abermule.

\begin{tabular}{lcc}
\hline $\begin{array}{l}\text { Fingerprint } \\
\text { Property }\end{array}$ & $\begin{array}{c}\text { Wilks' } \\
\text { Lambda }\end{array}$ & $\begin{array}{c}\text { Cumualtive \% Source } \\
\text { Type Samples } \\
\text { Classified Correctly }\end{array}$ \\
\hline $\mathrm{Cu}$ & 0.0888 & 80.00 \\
$\mathrm{Zn}$ & 0.0011 & 96.67 \\
$\mathrm{~Pb}$ & 0.0010 & 96.67 \\
$\mathrm{Ni}$ & 0.0005 & 100.00 \\
dithionite Mn & 0.0003 & 100.00 \\
$\mathrm{Mg}$ & 0.0001 & 100.00 \\
\hline
\end{tabular}

Upper Severn study area. As the fingerprint property concentrations characterising each source type will exhibit variation, some caution is inevitably required in interpreting the mixing model estimates. However, the mean concentration values calculated for each individual source type effectively represent values generated from a mixture of samples taken from a range of representative sites within the study area. It is therefore reasonable to assume that these mean values are directly comparable to the corresponding concentrations for suspended sediment samples or overbank deposits originating from a range of sites representing each individual source type.

The particle size correction factor $Z$ is incorporated into the mixing model algorithm to permit a direct comparison between the fingerprint property concentrations of either the contemporary suspended sediment samples or the floodplain core horizons, and the contemporary catchment source materials. For quantifying present sediment sources, the ratio of the specific surface area of each individual suspended sediment sample to the mean specific surface area of each individual source type is utilised (see Collins et al., 1997a). Mean correction factors are presented in Table 5. The particle size correction factor used in the quantification of historical sediment provenance is calculated using the ratio of the specific surface area of each individual core horizon to the mean specific surface area of each source type (see Collins et al., 1997b). As examples, mean correction factors are presented in Table 6.

Table 5. Mean contemporary sediment particle size correction factors (ratio of sediment to source type mean specific surface area).

\begin{tabular}{lccc}
\hline & Forest & Pasture & Channel Bank \\
\hline Plynlimon & 1.17 & 1.03 & 0.93 \\
Abermule & 1.25 & 1.12 & 1.06 \\
\hline
\end{tabular}

An organic matter content correction factor is included in the mixing model for similar reasons (see Collins et al., 1997a). However, this particular correction is not used in the quantification of historical sediment provenance, because the negligible organic carbon concentrations, which could be expected to characterise the lower horizons in any given floodplain core, negate the calculation of $O$ in equation 3 (see Collins et al., 1997b). The correction fac-

Table 6. Mean historical sediment particle size correction factors for the Upper Severn above Abermule (ratio of core horizon to source type mean specific surface area).

\begin{tabular}{ccc}
\hline Forest & Pasture & Channel Bank \\
\hline 0.95 & 0.95 & 0.87 \\
\hline
\end{tabular}


Table 7. Mean contemporary sediment organic matter content correction factors (ratio of sediment to source type mean organic carbon content).

\begin{tabular}{lccc}
\hline & Forest & Pasture & Channel Bank \\
\hline Plynlimon & 0.61 & 0.43 & 0.56 \\
Abermule & 0.85 & 1.20 & 2.90 \\
\hline
\end{tabular}

Table 8. Tracer specific weightings.

\begin{tabular}{lc}
\hline Fingerprint Property & Weighting $\left(\mathrm{W}_{\mathrm{i}}\right)$ \\
\hline $\mathrm{N}$ & 0.459 \\
$\mathrm{Cu}$ & 0.664 \\
${ }^{137} \mathrm{Cs}$ & 0.105 \\
$\mathrm{Zn}$ & 0.353 \\
$\mathrm{~Pb}$ & 0.200 \\
$\mathrm{Ni}$ & 0.140 \\
dithionite $\mathrm{Mn}$ & 0.503 \\
$\mathrm{Mg}$ & 0.489 \\
\hline
\end{tabular}

tor employed in the estimation of contemporary sediment provenance is calculated in the same manner as that for particle size; mean values are shown in Table 7.

Tracer specific weighting $W i$ is used in the mixing model to ensure that the fingerprint property providing the greatest precision within each composite signature exerts the greatest influence on the mixing model estimations based upon that signature (see Collins et al., 1997a). Weightings are presented in Table 8.

The goodness-of-fit provided by the mixing model estimates for present and past sediment sources was tested. This involved a comparison between the actual fingerprint property concentrations measured in either individual sediment samples or core horizons and the corresponding values predicted by the model, based on the best estimates for the percentage contributions from each source type, respectively (see Collins et al., 1997a; 1997b). Tables 9 and 10 indicate that the mean relative errors are typically of the order of $\pm 10 \%$. This confirms that the optimized mixing model provides an acceptable prediction of the fingerprint property concentrations associated with either individual suspended sediment samples or core horizons. Nonetheless, it is important to recognise that, although a reasonable agreement between simulated and observed fingerprint property data is a necessary condition for a successful mixing model, it is not a sufficient criterion for model verification (Betson and Ardis, 1978). Validation requires sediment source information provided by alternative techniques e.g. direct monitoring programmes.

A further test of the sensitivity of the model output to the variability of fingerprint property concentrations characterising each individual source type involved repeating the mixing model solutions for individual sediment samples or core horizons, using \pm 2 S.E. of the source material sample means. In each case, the estimates for the relative contributions from individual source types remained similar (a maximum change of $6.0 \%$ ) and in the same order of relative importance.

\section{Results and Discussion}

\section{CONTEMPORARY SEDIMENT PROVENANCE}

Figures 2 and 3 present the mean results of the mixing model calculations for each of the suspended sediment sampling sites within the Plynlimon headwater catchment and the site at Abermule, respectively. Contributions from the surface erosion of forest soils are highest for the Hafren $(76.9 \%)$ and lowest for the Upper Hore $(10.8 \%)$ gauging stations. Enhanced erosion of forest soils is associated with forestry operations at Plynlimon and three main activities in particular: (1) construction of plough furrows and drains; (2) road or track construction or modification; and (3) the general mechanical disturbance of the catchment surface (Marks, 1994). These activities, by increasing the surface erosion of forest soils throughout the forest rotation, result in suspended sediment concentrations stabilising well above pre-afforestation levels (Francis and Taylor, 1989). Track and road construction using heavy plant machinery and explosives, road modification to improve accessibility and turning, as well as the provision of timber processing, stacking and loading bays, all promote the widespread erosion of forest soils (Leeks, $1986 ;$ 1992). Sediment mobilised by these activities is transported directly to the stream network via road drains and culverts (Leeks, 1992). Mechanical disturbance of the catchment surface is associated primarily with the use of heavy felling machinery e.g. forwarders and skidders. Leeks and Roberts (1987) estimated that such disturbances increase sediment concentrations by an order of magnitude

Table 9. Mean percentage relative errors for the mixing model estimates for contemporary sediment provenance.

\begin{tabular}{lcc}
\hline Flow Gauging Station & Mean \% Error & S.E. Mean \\
\hline Hafren & 11.5 & 1.25 \\
Upper Hore & 10.4 & 1.41 \\
Severn Trapezoidal Flume & 9.2 & 1.13 \\
Abermule & 10.1 & 1.33 \\
\hline
\end{tabular}

Table 10. Mean percentage relative error for the mixing model estimates for historical sediment provenance at Abermule.
Mean \% Error
S.E. Mean 

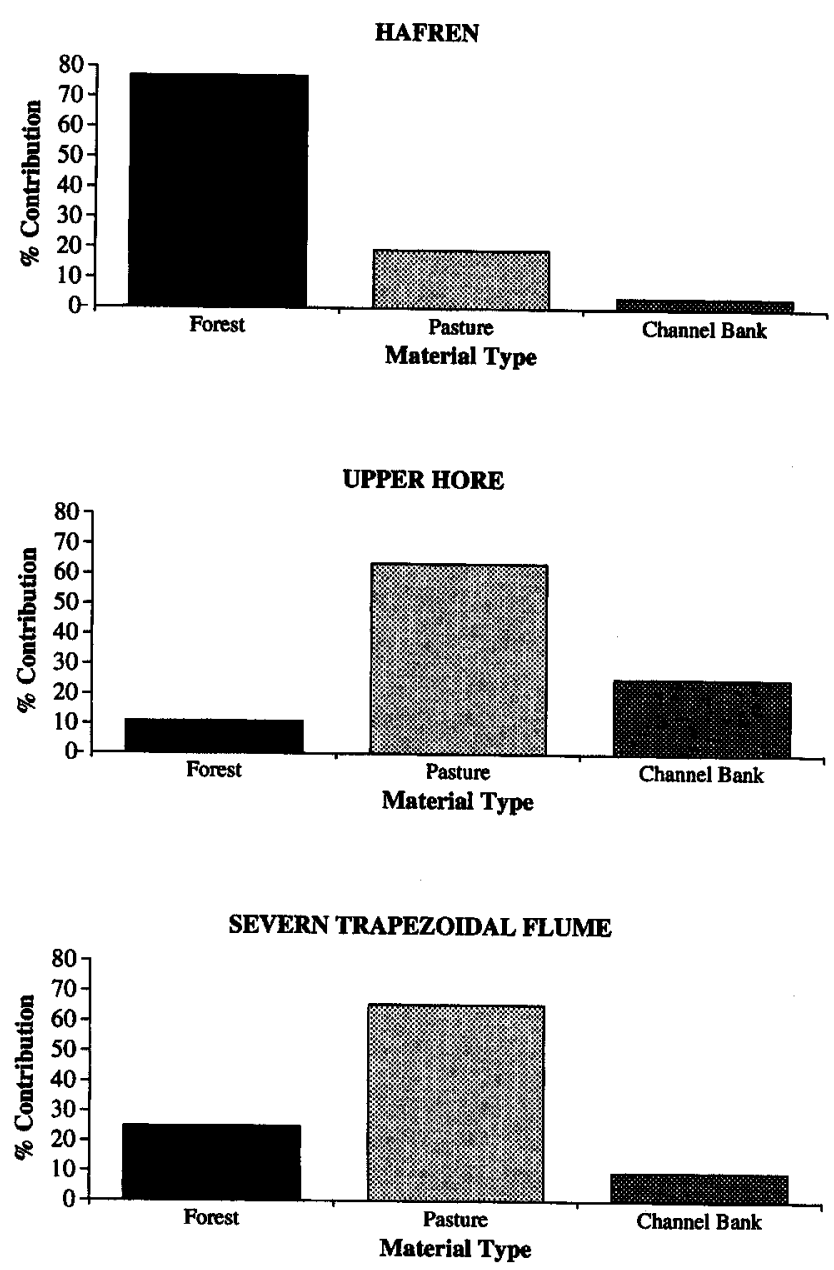

Fig. 2. Mean mixing model estimates for the relative contributions from individual source types to the suspended sediment load sampled at each flow gauging station in the Plynlimon headwater catchment.

for moderate to high flows. The severity of this erosion of forest soils in the headwater catchment at Plynlimon is further demonstrated by the high contribution from forest areas estimated for the sediment load sampled downstream at Abermule $(48.0 \%)$. This indicates that the consequences of disruptive forestry activities within the headwaters of the River Severn are dispersed downstream. In response to this severe erosion, minimum disturbance timber harvesting techniques e.g. cable crane extraction or skylining have become more popular (cf. Leeks and Roberts, 1987; Maitland et al., 1990).

Surprisingly, given the dominance of forest in the Plynlimon headwater catchment, sediment contributions from the surface erosion of pasture soils are most important for the Upper Hore and Severn Trapezoidal Flume gauging stations. Surface erosion in pasture areas has been associated with sheep burrowing (Thomas, 1964) and sheetwash associated with the high energy fluvial system promoted by the local steep slopes (Rudeforth et al., 1984). The surface erosion of forest soils is not the dominant source for the Upper Hore sampling site, as this is upstream of the area drained by this particular tributary which was subjected to an experiment (initiated in 1985) to investigate the role of clearfelling in enhancing suspended sediment yields from forest sources (cf. Leeks and Roberts, 1987). In addition, the Upper Hore itself was planted with forest in 1963-1964 and is a steep, freely draining catchment, with the result that sediment outputs from this now mature forest plantation are likely to have stabilised. Further downstream at Abermule, pasture contributions remain important $(30.0 \%)$, reflecting the poaching of pasture surfaces and localised erosion during high intensity rainfall events.

Eroding channel banks are generally the least significant sediment source, although a mean contribution of $25.5 \%$ and $22.0 \%$ is calculated for the Upper Hore and Abermule flow gauging stations, respectively. Severe bank erosion in the Plynlimon headwater catchment is promoted by log jams and debris dams (Leeks and Roberts, 1987), following extreme hydrological events (Lawler and Leeks, 1992), as well as by the crossing of streams by heavy plant machinery (Marks, 1994); the last mentioned problem has resulted in the recommendation that heavy machines should not be permitted to work in streams (Forestry Commission, 1988; 1993). Extensive bank erosion is widespread between Plynlimon and Abermule and is particularly evident at Morfodion and Maesmawr (see Fig. 1B).

Because a large proportion of the two main tributary

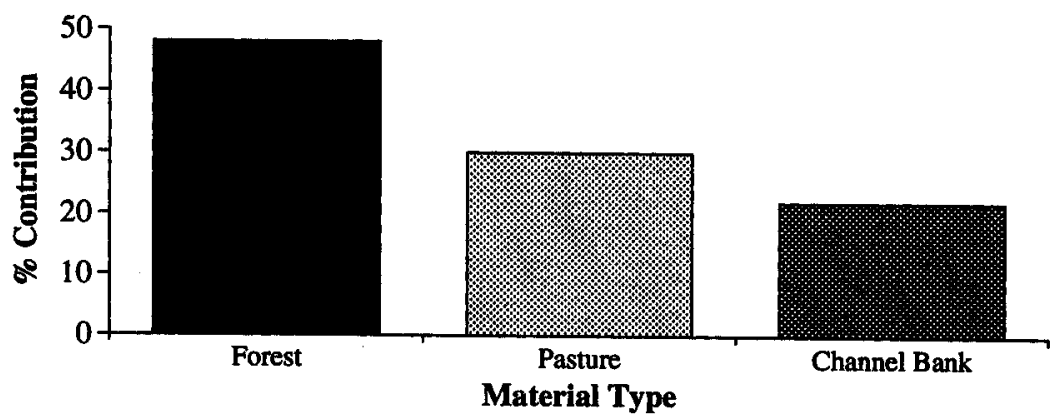

Fig. 3. Mean mixing model estimates for the relative contributions from individual source types to the suspended sediment load sampled at the Abermule flow gauging station. 
HAFREN

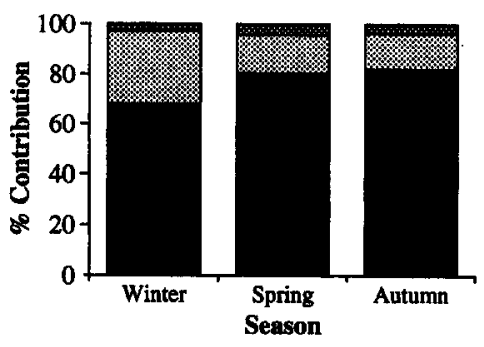

SEVERN TRAPEZOIDAL FLUME

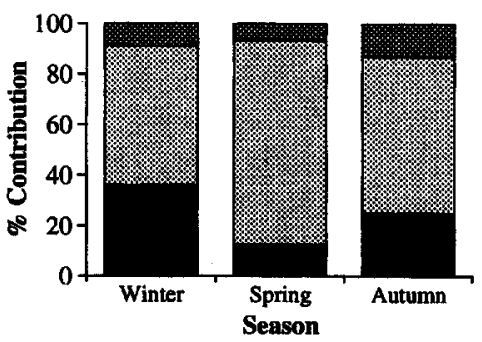

UPPER HORE
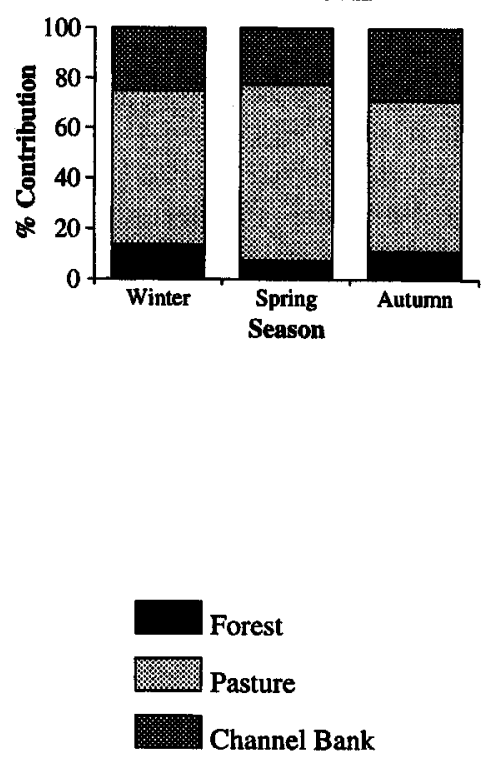

Fig. 4. Mixing model estimates for the seasonal mean relative contributions from individual source types to the sediment load sampled at each flow gauging station in the Plynlimon headwater catchment.

subcatchments within the experimental catchment $(48.0 \%$ of the Hafren tributary and $78.0 \%$ of the Lower Hore) are forested, the dominance of pasture contributions to the suspended sediment load sampled at the Severn Trapezoidal Flume flow gauging station is most surprising. However, the small number of suspended sediment samples collected during flood events at the Severn Trapezoidal Flume flow gauging station may not have adequately characterised the typical storm response at this site.

Further analysis of the mixing model results for contemporary suspended sediment provenance involved grouping the floods during which suspended sediment samples were collected into winter (Dec, Jan, Feb), spring (Mar, Apr, May) and autumn (Sep, Oct, Nov) events. Unfortunately, no summer flood samples were available. The contributions estimated for each source type for each flood event sampled within each season, were then averaged to provide the mean seasonal contribution from individual source types to the suspended sediment load sampled at each flow gauging station (see Fig. 4 and 5). Contributions from the surface erosion of forest soils are highest during autumn at the Hafren $(82.0 \%)$ and during winter at the Upper Hore (13.7\%), Severn Trapezoidal Flume $(36.2 \%)$ and Abermule $(65.0 \%)$ sampling sites. These tendencies coincide with the catchment disturbance associated with the logging activities of the Forestry Commission during autumn and winter (cf. Leeks and Roberts, 1987). Although logging activities occur throughout the year, it is during autumn and winter that the downstream impacts become most apparent as it is during these seasons that disrupted forest soils are more readily mobilised by higher rainfalls and stream discharges. The surface erosion of pasture soils exhibits less seasonal variability because such areas are not as influenced by seasonal disturbances. Channel bank contributions are higher during spring (e.g. $4.3 \%$ at the Hafren and $26.0 \%$ at Abermule) and autumn (e.g. 29.0\% at the Upper Hore and $13.1 \%$ at the Severn Trapezoidal Flume). Higher discharges, reduced vegetation cover for channel bank surfaces, the greater efficacy of physical weathering processes e.g. freeze-thaw and bank erosion by timber harvesting machinery are all likely to promote higher contributions from channel banks during spring and autumn floods.

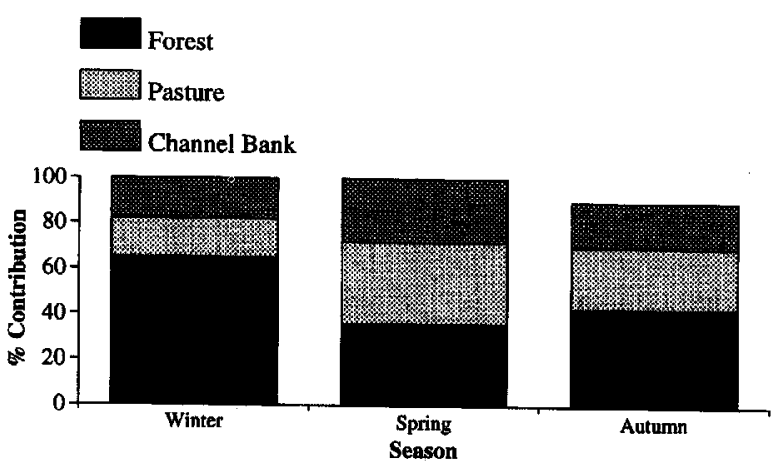

Fig. 5. Mixing model estimates for the seasonal mean relative contributions from individual source types to the sediment load sampled at the Abermule flow gauging station. 


\section{SEDIMENT PROVENANCE OVER THE RECENT PAST}

Figure 6 presents a ${ }^{137} \mathrm{Cs}$ depth-profile for the floodplain core collected at Abermule. Peaks of $50.0 \mathrm{mBq} \mathrm{g}{ }^{-1}$ and $192.2 \mathrm{mBq} \mathrm{g} \mathrm{g}^{-1}$ are observed at the $22-24 \mathrm{~cm}$ and $4-6 \mathrm{~cm}$ horizons respectively. Taking the former as the peak of atomic weapons testing in 1963 and the latter as the Chernobyl accident of April 1986, permits the calculation of time-averaged deposition rates of $0.73 \mathrm{~cm} \mathrm{yr}^{-1}$ for the past 33 years and $0.60 \mathrm{~cm} \mathrm{yr}^{-1}$ for the past 10 years, respectively. Assuming that these values can be extrapolated over the entire period represented by this core, the $32 \mathrm{~cm}$ of deposited sediment in this floodplain profile represents between 43.8 and 53.3 years of catchment history (see timescale on Fig. 7).

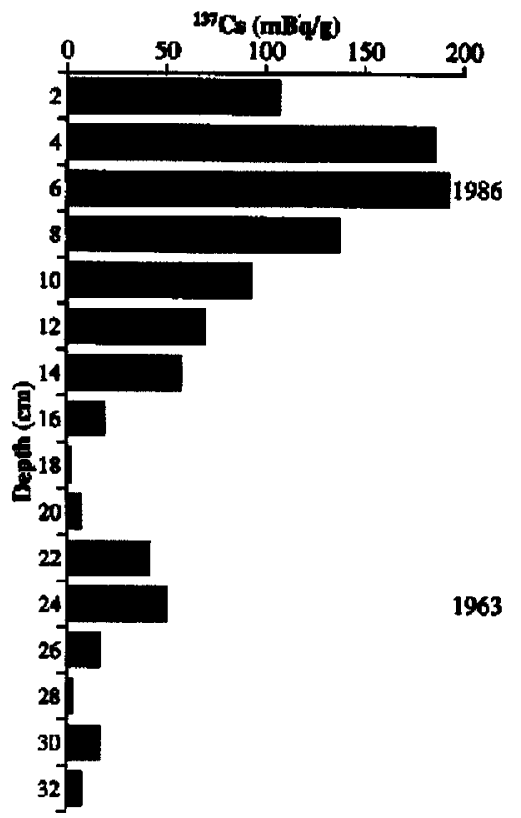

Fig. 6. ${ }^{137} \mathrm{Cs}$ depth-profile for the Abermule floodplain core.

Figure 7 examines the results provided by the mixing model for recent changes in the relative contributions from each individual source type comprising the Upper Severn. The significant downcore fluctuations in sediment provenance during recent flood events resulting in overbank deposition, imply that the Upper Severn has experienced considerable environmental disturbance over the past 43.8-53.3 years. Contributions from the surface erosion of forest soils are most important in the lower half of the core, with maximum $(70.5 \%)$ and minimum $(1.0 \%)$ inputs being estimated for the $20-22 \mathrm{~cm}$ and $0-2 \mathrm{~cm}$ horizons, respectively. Sediment contributions from the surface erosion of pasture soils are dominant in the upper half of the core, with a maximum (92.0\%) and minimum (10.0\%) input being estimated for the $46 \mathrm{~cm}$ and $18-20 \mathrm{~cm}$ horizons, respectively. Channel bank contributions are generally low throughout the $43.8-53.3$ years represented by the

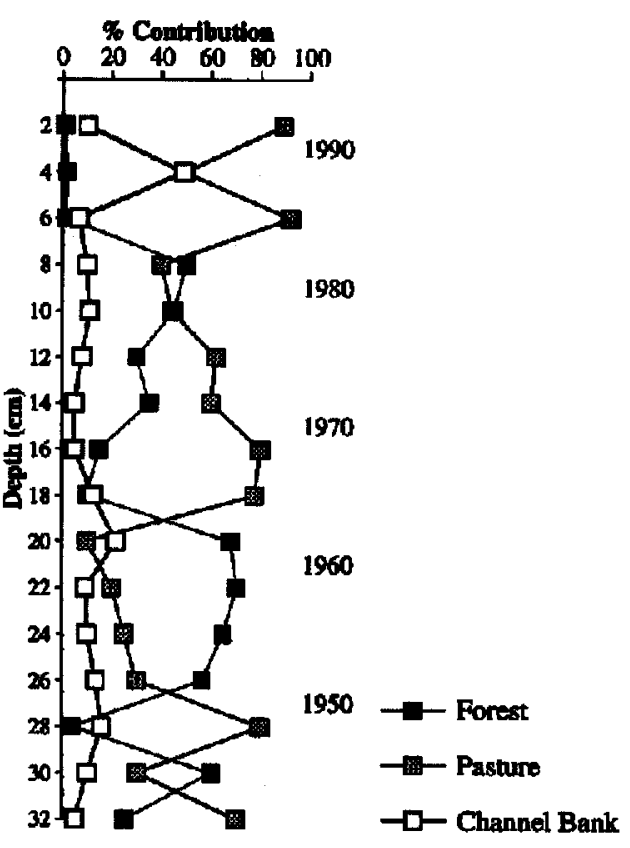

Fig. 7. Mixing model estimates for recent variations in the relative contributions from individual source types to the overbank sediment profile sampled at Abermule.

Abermule floodplain profile. A maximum contribution of $48.7 \%$ is estimated for the $2-4 \mathrm{~cm}$ horizon, whilst a minimum of $5.0 \%$ is estimated for the $12-16 \mathrm{~cm}$ and $30-32$ cm horizons.

The increase in the sediment contributions from eroding forest soils, evident for the $8-16 \mathrm{~cm}$ horizons, most probably reflects catchment disturbance associated with extensive afforestation during the mid-1960s. Afforestation with Sitka spruce and Lodgepole pine in the Hafren, Tanllwyth and Hore sub-catchments at Plynlimon during 1963-1964 and the associated road building and insertion of land drains resulted in the mobilisation of sediment from previously undisturbed areas of the Upper Severn catchment. Figure 7 demonstrates that this widepread mobilisation of forest soils continued throughout the 1970s. Enhanced erosion of the disturbed areas was aided by a significant increase in the peak of storm flows, with the typical time lag between the centroid of storm rainfall and consequent peak river flow being reduced from $2.7 \mathrm{hrs}$ to $1.8 \mathrm{hrs}$. In contrast, the more restricted deforestation experiment involving the clearfelling of 157 ha in the Hore sub-catchment alone, which resulted in an increase in annual suspended sediment yields from $24.4 \mathrm{t} \mathrm{km}^{-2} \mathrm{yr}^{-1}$ to $57.1 \mathrm{t} \mathrm{km}^{-2} \mathrm{yr}^{-1}$ (Leeks and Roberts, 1987), caused no corresponding rise in forest contributions to the floodplain sediment profile sampled downsteam at Abermule. Increments in the relative contributions from forest sources estimated for the $20-26 \mathrm{~cm}$ horizons are likely to reflect the continuing impact throughout the 1950s of disturbances associated with the planting of Norway spruce and Lodgepole pine in the Hafren, Tanllwyth and Lower 
Hore sub-catchments of Plynlimon during 1948-1950 (Kirby et al., 1991).

Major contributions from the surface erosion of pasture soils in the Upper Severn have been promoted by a $30 \%$ increase in the number of livestock grazing units to 100 per 100 ha between 1947-1971 (Rudeforth et al., 1984). Intensification has been associated with extensive pasture re-seeding and general improvement programmes during the 1960s and 1970s, as well as recent increases in the use of NPK fertilisers. Widespread poaching of pasture surfaces has been the result (Rudeforth et al., 1984).

Sediment contributions from eroding channel banks have remained fairly stable during the time period represented by the Abermule floodplain core. Peak contributions are likely to reflect periods of enhanced channel margin erosion associated with high discharges during extreme hydrological events, damage by heavy machinery, poaching by sheep or cattle and the circumvention of $\log$ jams and debris dams by local streams.

\section{Conclusion}

A composite fingerprinting technique has quantified the relative contributions of sediment from individual source types in the Upper Severn catchment both at present and during the recent past. In both cases, eroding surface soils represent the major sediment source, thereby highlighting the significance of anthropogenic activity associated with commercial coniferous forestry and the intensification of livestock farming. Ploughing and land drainage, road construction or modification, as well as mechanical disturbance or the poaching and burrowing of forest and pasture surface soils can all result in chronic erosion. If the adverse effects of forestry and agriculture on upland catchment environments are to be minimized, the sediment provenance data provided by techniques such as the composite fingerprinting approach, must be used to help produce well-informed guidelines regarding the continuing manipulation and management of such areas.

\section{Acknowledgements}

The authors are indebted to the Natural Environment Research Council and the Institute of Hydrology for funding a CASE Postgraduate Studentship (ALC). Staff at Plynlimon provided valuable assistance with the collection of storm samples. Helen Jones produced the diagrams.

\section{References}

Allen, S.E., 1989. Chemical Analysis of Ecological Materials. Blackwell, Oxford, 368 pp.

Bascomb, C.L., 1968. Distribution of pyrophosphate-extractable iron and organic carbon in soils of various groups. 7. Soil Sci., 19: 251-268.

Betson, R.P. and Ardis, C.V., 1978. Implications for modelling surface-water hydrology. In: M.J. Kirkby (Editor), Hillslope Hydrology. Wiley, Chichester, UK, pp. 295-323.

Bonnett, P.J.P., Leeks, J.G.L. and Cambray, R.S., 1989. Transport processes for Chernobyl-labelled sediments: preliminary evidence from upland Wales. Land Degrad. Rehabil., 1: 39-50.

Braune, E. and Looser, U., 1990. Cost impacts of sediments in South African rivers. In: R.F. Hadley and E.D. Ongley (Editors), Sediment and the Environment. IAHS Publ. no. 184, IAHS Press, Wallingford, pp. 131-144.

Brown, A.G., 1985. The potential use of pollen in the identification of suspended sediment sources. Earth Surf. Process. Landforms, 10: 27-32.

Caitcheon, G.G., 1993. Applying environmental magnetism to sediment tracing. In: N.E. Peters, E. Hoehn, Ch. Leibundgut, N. Tase and D.E. Walling (Editors), Tracers in Hydrology. IAHS Publ. no. 215, IAHS Press, Wallingford, pp. 285-292.

Collins, A.L., 1995. The Use of Composite Fingerprints for Tracing the Source of Suspended Sediment in River Basins. Unpublished Ph.D. Thesis, University of Exeter, UK, 548 pp.

Collins, A.L., Walling, D.E. and Leeks, G.J.L., 1996. Composite fingerprinting of the spatial source of fluvial suspended sediment: A case study of the Exe and Severn River basins, UK. Geomorphologie: Relief, Processes, Environnement, 2: 41-54.

Collins, A.L., Walling, D.E. and Leeks, G.J.L., 1997a. Source type ascription for fluvial suspended sediment based on a quantitative composite fingerprinting technique. Catena, 29: 1-27.

Collins, A.L., Walling, D.E. and Leeks, G.J.L., 1997b. Use of the geochemical record preserved in floodplain deposits to reconstruct recent changes in river basin sediment sources. Geomorph. 19, 151-167.

Cordone, A.J. and Kelley, D.W., 1961. The influences of inorganic sediment on the aquatic life of streams. Calif. Fish Game, 47: 189-228.

Deb, B.C., 1950. The estimation of free iron oxides in soils and clays and their removal. f. Soil Sci., 1: 212-220.

Duck, R.W. and McManus, J., 1987. Soil erosion near Barry, Angus. Scot. Geogr. Mag., 103: 44-46.

Forestry Commission, 1988. Forests and Water Guidelines (First Edition). HMSO, London.

Forestry Commission, 1993. Forests and Water Guidelines (Third Edition). HMSO, London.

Foster, I.D.L. and Walling, D.E., 1994. Using reservoir deposits to reconstruct changing sediment yields and sources in the catchment of the Old Mill Reservoir, South Devon, over the past 50 years. F. Hydrol. Sci., 39: 347-368.

Francis, I.S. and Taylor, J.A., 1989. The effect of forestry drainage operations on upland sediment yields: a study of two peat-covered catchments. Earth Surf. Process. Landforms, 14: 73-83.

Garrad, P.N. and Hey, D., 1989. Sources of suspended and deposited sediment in a Broadland river. Earth Surf. Process. Landforms, 14: 41-62.

Grimshaw, D.L. and Lewin, J., 1980. Source identification for suspended sediment. 7. Hydrol., 47: 151-162.

Haigh, M.J., 1977. The use of erosion pins in the study of slope evolution. In: Shorter Technical Methods (II), British Geomorphological Research Group Technical Bulletin, 13, pp. 31-49.

$\mathrm{He}, \mathrm{Q}$. and Owens, P., 1995. Determination of suspended 
sediment provenance using Caesium-137, Unsupported Lead210 and Radium-226: a numerical mixing model approach. In: I.D.L. Foster, A.M. Gurnell and B.W. Webb (Editors), Sediment and Water Quality in River Catchments. Wiley, Chichester, UK, pp. 207-227.

Hudson, H.R., 1990. A case study of approaches for determining diffuse suspended sediment sources and processes. In: R.F. Hadley and E.D. Ongley (Editors), Sediment and the Environment. IAHS Publ. no. 184, IAHS Press, Wallingford, pp. 85-94.

Jones, R., Chambers, F.M. and Benson-Evans, K., 1991. Heavy metals $(\mathrm{Cu}$ and $\mathrm{Zn}$ ) in recent sediments of Llangorse Lake, Wales: non-ferrous smelting, Napoleon and the price of wheat - a palaeoecological study. Hydrobiol., 214: 149-154.

Kirby, C., Newson, M.D. and Gilman, K., 1991. Plynlimon Research: The First Two Decades. Institute of Hydrology, Report 109. Wallingford, UK.

Kirkbridge, M.P. and Reeves, A.D., 1993. Soil erosion caused by low-intensity rainfall in Angus, Scotland. Appl. Geogr. 13: 299-311.

Klages, M.G. and Hsieh, Y.P., 1975. Suspended solids carried by the Gallatin River of Southwestern Montana II: using mineralogy for inferring sources. F. Environ. Qual., 4: 68-73.

Knisel, W.G., 1980. CREAMS: A Field-scale Model for Chemicals, Runoff and Erosion from Agricultural Management Systems. U.S. Dep. Agric. Conserv. Res. Rep., 26.

Lambert, C.P. and Walling, D.E., 1986. Suspended sediment storage in river channels: a case study of the River Exe, Devon, UK. In: R.F. Hadley (Editor), Drainage Basin Sediment Delivery. IAHS Publ. no. 159, IAHS Press, Wallingford, pp. 263-276.

Lawler, D.M., 1992. Design and installation of a novel automatic erosion monitoring system. Earth Surf. Process. Landforms, 17: 455-463.

Lawler, D.M. and Leeks, G.J.L., 1992. River bank erosion events on the Upper Severn detected by the Photo-Electronic Erosion Pin (PEEP) system. In: J. Bogen, D.E. Walling and T. Day (Editors), Erosion and Sediment Transport Monitoring Programmes in River Basins. IAHS Publ. no. 210, IAHS Press, Wallingford, pp. 143-152.

Leeks, G.J.L., 1986. Artificially Induced Suspended Load Waves: The Effects of Streamside Explosions. Institute of Hydrology (Fluvial Unit), Plynlimon.

Leeks, G.J.L., 1992. Impact of plantation forestry on sediment transport processes. In: P. Billi, R.D. Hey, C.R. Thorne and P. Tacconi (Editors), Dynamics of Gravel-bed Rivers, Wiley. Chichester, UK, pp. 651-673.

Leeks, G.J.L. and Roberts, G., 1987. The effects of forestry on upland streams - with special reference to water quality and sediment transport. In: J.E.G. Good (Editor), Environmental Aspects of Plantation Forestry in Wales. Institute of Terrestrial Ecology, Grange-over-Sands, pp. 9-24.

Lewin, J. and Wolfenden, P.J., 1978. The assessment of sediment sources: a field experiment. Earth Surf. Process. Landforms, 3: 171-178.

Loughran, R.J. and Campbell, B.L., 1995. The identification of catchment sediment sources. In: I.D.L. Foster, A.M. Gurnell and B.W. Webb (Editors), Sediment and Water Quality in River Catchments. Wiley, Chichester, UK, pp. 189-205.

Maitland, P.S., Newson, M.D. and Best, G.A., 1990. The Impact of Afforestation and Forestry Practice on Freshwater
Habitats. Nature Conservancy Council, Focus on Nature Conservation, 23.

Marks, S.D., 1994. Fluvial particulate inputs from afforested catchments: origins and impacts. In: C.N. Gibbins and D.A. Turnbull (Editors), Human Impact on Freshmater Systems. Department of Environment, University of Northumbria, pp. 1-17.

McManus, J., 1988. Grain size determination and interpretation. In: M. Tucker (Editor), Techniques in Sedimentology. Blackwell, Oxford, pp. 63-85.

Murray, A.S., Olive, L.J., Olley, J.M., Caitcheon, G.G., Wasson, R.J. and Wallbrink, P.J., 1993. Tracing the source of suspended sediment in the Murrumbidgee River, Australia. In: N.E. Peters, E. Hoehn, Ch. Leibundgut, N. Tase and D.E. Walling (Editors), Tracers in Hydrology. IAHS Publ. no. 215, IAHS Press, Wallingford, pp. 293-302.

Oldfield, F. and Clark, R.L., 1990. Lake sediment-based studies of soil erosion. In: J. Boardman, I.D.L. Foster and J.A. Dearing (Editors), Soil Erosion on Agricultural Land. Wiley, Chichester, pp. 201-228.

Oldfield, F., Rummery, T.A., Thompson, R. and Walling, D.E., 1979. Identification of suspended sediment sources by means of magnetic measurements: some preliminary results. Wat. Resour. Res., 15: 211-219.

Olsen, S.R. and Dean, L.A., 1965. Phosphorus. In: C.A. Black (Editor), Methods of Soil Chemical Analysis Part 2. American Society of Agronomy, Madison, Wisconsin, pp. 1035-1049.

Ongley, E.D., Bynoe, M.C. and Percival, J.B., 1981. Physical and geochemical characteristics of suspended solids, Wilton Creek, Ontario. Can. 7. Earth Sci., 18: 1365-1379.

Ongley, E.D., Krishnappan, B.G., Droppo, I.G., Rao, S.S. and Maguire, R.J., 1992. Cohesive sediment transport: emerging issues for toxic chemical management. Hydrobiol., 235/236: 177-187.

Peart, M.R., 1993. Using sediment properties as natural tracers for sediment source: two case studies from Hong Kong. In: N.E. Peters, E. Hoehn, Ch. Leibundgut, N. Tase and D.E. Walling (Editors), Tracers in Hydrology. IAHS Publ. no. 215, IAHS Press, Wallingford, pp. 313-318.

Peart, M.R. and Walling, D.E., 1986. Fingerprinting sediment source: the example of a drainage basin in Devon, UK. In: R.F. Hadley (Editor), Drainage Basin Sediment Delivery. IAHS Publ. no. 159, IAHS Press, Wallingford, pp. 41-55.

Peart, M.R. and Walling, D.E., 1988. Techniques for establishing suspended sediment sources in two drainage basins in Devon, UK: a comparative assessment. In: M.P. Bordas and D.E. Walling (Editors), Sediment Budgets. IAHS Publ. no. 174, IAHS Press, Wallingford, UK, pp. 269-279.

Qui, X-C. and Zhu, Y-Q., 1993. Rapid analysis of cation exchange properties in acidic soils. F. Soil Sci., 155: 301-308.

Ritchie, J.C., Grissinger, E.H., Murphy, J.B. and Garbrecht, J.D., 1994. Measuring channel and gully cross-sections with an airborne laser altimeter. Hydrol. Processes, 8: 237-243.

Rudeforth, C.C., Hartnup, R., Lea, J.W., Thompson, T.R.E. and Wright, P.S., 1984. Soils and their Use in Wales. Soil Survey of England and Wales, Bulletin 11, Harpenden, 336 pp.

Salomans, W., 1975. Chemical and isotopic composition of carbonates in recent sediments and soils from Western Europe. 7 . Sediment. Petrol., 45: 440-449.

Salomans, W. and Eysink, W.D., 1981. Pathways of mud and 
particulate trace metals from rivers to the southern North Sea. Spec. Publ. Inter. Assoc. Sedimentol., 5: 429-450.

Santiago, S., Thomas, R.L., Loizeau, J-L., Favargar, P-Y. and Vernet, J-P., 1992. Further discussion on the intercomparison of the trace metal concentrations and particle size of fluvial sediment recovered from two centrifuge systems. Hydrol. Processes, 4: 283-287.

Slattery, M.C., Burt, T.P. and Walden, J., 1995. The application of mineral magnetic measurements to quantify within-storm variations in suspended sediment sources. In: Ch. Leibundgut (Editor), Tracer Technologies for Hydrological Systems. IAHS Publ. no. 229, IAHS Press Wallingford, pp. 143-151.

Sutherland, R.A. and Bryan, R.B., 1990. Flow dynamics and the variability of suspended sediment in a semi-arid tropical stream, Baringo District, Kenya. Geogr. Ann., 72A: 23-39.

Thomas, T.M., 1964. Sheet erosion by sheep in the Plynlimon area. British Geomorphological Research Group, Occas. Publ. 2: 11-14.

Toy, T.J., 1983. A linear erosion/elevation measuring instrument (LEMI). Earth Surf. Processes Landforms, 8: 313-322.

UNESCO, 1978. Monitoring of particulate matter quality in rivers and lakes-recommendations of a morkshop on the assessment of particulate matter contamination in rivers and lakes. UNESCO/GEMS/WATER: MED-IX/BUD/Report.

Wall, G.J. and Wilding, L.P., 1976. Mineralogy and related parameters of fluvial suspended sediments in Northwestern Ohio. 7. Environ. Qual., 5: 168-173.

Walling, D.E., 1990. Linking the field to the river: sediment delivery from agricultural land. In: J. Boardman, I.D.L. Foster and J.A. Dearing (Editors), Soil Erosion on Agricultural Land. Wiley, Chichester, pp. 129-152.

Walling, D.E. and He, Q., 1992. Interpretation of caesium-137 profiles in lacustrine and other sediments: the role of catchment-derived inputs. Hydrobiol., 235/236: 219-230.
Walling, D.E. and Kane, P., 1984. Suspended sediment properties and their geomorphological significance. In: T.P. Burt and D.E. Walling (Editors), Catchment Experiments in Fluvial Geomorphology. GeoBooks, Norwich, pp. 311-334.

Walling, D.E. and Webb, B.W., 1987. Suspended load in gravel bed rivers: UK experience. In: C.R. Thorne; J.C. Bathurst and R.D. Hey (Editors), Sediment Transportation in Gravel-bed Rivers. Wiley, Chichester, pp. 691-723.

Walling, D.E. and Woodward, J.C., 1992. Use of radiometric fin= gerprints to derive information on sediment sources. In: J. Bogen, D.E. Walling and T. Day (Editors), Erosion and Sediment Transport Monitoring Programmes in River Basins. IAHS Publ. no. 210, IAHS Press, Wallingford, pp. 153-163.

Walling, D.E. and Woodward, J.C., 1995. Tracing sources of suspended sediment in river basins: A case study of the River Culm, Devon, UK. Mar. Freshwater Res., 46: 327-336.

Walling, D.E., Woodward, J.C. and Nicholas, A.P., 1993. A multi-parameter approach to fingerprinting suspended sediment sources. In: N.E. Peters, E. Hoehn, Ch. Leibundgut, N. Tase and D.E. Walling (Editors), Tracers in Hydrology. IAHS Publ. no. 215, IAHS Press, Wallingford, UK, pp. 329-337.

Woodward, J.C., Lewin, J. and Macklin, M.G., 1992. Alluvial sediment sources in a glaciated catchment: The Voidomatis Basin, Northwestern Greece. Earth Surf. Process. Landforms, 17: 205-216.

Yu, L. and Oldfield, F., 1989. A multivariate mixing model for identifying sediment source from magnetic measurements. Quatern. Res., 32: 168-181.

Yu, L. and Oldfield, F., 1993. Quantitative sediment source ascription using magnetic measurements in a reservoir system near Nijar, S.E. Spain. Earth Surf. Process. Landforms, 18: 441-454. 